RAD Conference Proceedings, vol. 3, pp. 94-97, 2018

ISSN 2466-4626 (online) | DOI: 10.21175/RadProc.2018.20

www.rad-proceedings.org

\title{
URANIUM IN FOODSTUFF SAMPLES FROM TWO REGIONS IN BULGARIA WITH RELATIVELY HIGH LOCAL LEVELS OF RADIOACTIVE BACKGROUND
}

\author{
Radoslava Lazarova*, Ivanka Yordanova, Donka Staneva
}

“N. Poushkarov” Institute of Soil Science, Agrotechnologies and Plant Protection, Sofia, Bulgaria

\begin{abstract}
Bulgaria is a country which developed uranium $(U)$ mining in the past. In the present study $U$ content in different foodstuffs was determined in answer to public concern of possible radiological risk raised by relatively high $U$ concentration measured in drinking waters in the regions of Haskovo and Plovdiv. Around them uranium mining was carried out on a large scale in the past (around Haskovo under the classical mining method and around Plovdiv under the method of geotechnological drilling). Vegetable (alfalfa, carrots, potatoes and tomato paste) and animal (milk and minced meat) samples were studied and radioactivity concentration (Bq. $\mathrm{kg}^{-1}$ ) of two natural $U$ isotopes was determined in the following intervals: $U-234-0.004-1.00$ and $U-238-0.004-0.76$. Calculated natural $U$ concentration $(\mathrm{mg} / \mathrm{kg})$ was 0.0010 - 0.0712. Results were comparable with data cited in literature for $U$ content in foodstuffs from former U mining regions in Europe and considered not radiologically hazardous to the population.
\end{abstract}

Key words: Food, natural radioactivity, uranium

\section{INTRODUCTION}

The amount of ${ }^{238} \mathrm{U},{ }^{226} \mathrm{Ra},{ }^{232} \mathrm{Th}$ and ${ }^{40} \mathrm{~K}$ in soils depends on the parent rock and the processes of soil formation. The analysis of the radionuclide content of soil, plants, water and knowledge of radionuclides behaviour in the soil-plant system provides an important part of the data basis for dose estimation $[1,2]$. The assessment of the activity concentration of natural radionuclides is of importance as the principles of long-term environmental and human protection must take into account the natural background [3] .

Human activities can cause accumulation of radioactive elements, thus modifying natural concentrations. Examples of this are found in former uranium mining areas [4].

After the uranium mining closure in Bulgaria, environmental restoration was planned and certain remediation activities were implemented $[5,6,7]$. Along with the above-mentioned activities, radiological monitoring of underground and surface waters has been carried out since 1998.

Furthermore, conservative requirements for drinking water were provided for in Directive 98/83/EC [8]. National legislation was fully harmonized with EU Directives. One of the main normative acts in this area is Regulation No. 9 of 16.03.2001 on the quality of water intended for drinking and household use [9] in which the maximum reference value of natural uranium is $0.03 \mathrm{mg} / \mathrm{l}$.

For the estimation of the radiation doses for various groups of population, the determination of uranium ingestion through foodstuffs is essential. UNSCEAR estimates the annual intake of U-238 by adults at 5.7 $\mathrm{Bq}[1]$.

Some of the most comprehensive studies on dietary intake of natural uranium have been carried out in the United States by Welford and Beard [10] and Fisenne et al. [11], who reported a daily intake of uranium of $30.3 \mathrm{mBq}$ for New York citizens. Nozaki, at al. [12] from Japan reported uranium intake of $32.86 \mathrm{mBq}$, while Hamilton [13] reported a $25.28 \mathrm{mBq}$ intake for adults in the United Kingdom. In another study by Kumar at al., daily intake of uranium from food products excluding water for the residents of three villages in India - Giana, Jajjal and Malkana (Bathinda district, Punjab) [14] was reported to be 1.04, 0.99 and $0.66 \mathrm{~Bq}$ a day respectively.

During the annual monitoring of drinking water in Bulgaria, relatively high uranium concentrations were measured in 2017 in the regions of Plovdiv and Haskovo. Due to possible radiological hazard to the population in the regions, the aim of the present study was to analyze U content in certain foodstuffs ingested on a daily basis and such used for feed.

\section{MATERIALS AND METHODS}

Samples of alfalfa, carrots, potatoes, tomato concentrate, fresh milk and minced meat from the regions of Plovdiv and Haskovo were analyzed.

Samples of alfalfa, carrots and potatoes were first dried at $110^{\circ} \mathrm{C}$. Concentrated nitric acid was added to all the samples to destroy organic matter and the

*radoslava2005@abv.bg 
R. Lazarova et al., Uranium in foodstuff samples from two regions..., RAD Conf. Proc., vol. 3, 2018, 94-97

samples were first dried on sand bath and then ashed in a muffle furnace at $55^{\circ}$.

The basic method used for measuring content of $\mathrm{U}$ isotopes in the samples had been previously developed and validated by the Testing Laboratory of Radioecology and Radioisotopic Research $[15,16]$.

Aliquot parts (2 g) of ashed samples of alfalfa, milk and minced meat were analysed according to this method by extraction with trioctylphosphine oxide (TOPO), backextraction with $\mathrm{NH}_{4} \mathrm{~F}$, coprecipitation with $\mathrm{LaF}_{3}$, anion exchange and electroplating from $\mathrm{HCl} /$ oxalate solution.

In the case of carrots, potatoes and tomato concentrate full preliminary dissolution of the aliquot parts of ashed samples was achieved and procedure was reduced to the following one presented in Fig. 1. This procedure had been previously developed by the Laboratory for measuring $U$ isotopes in water where full dissolution of the analysed aliquot part is obtained in the beginning. The short method applied is validated by participation in Interlaboratory Comparisons organized by IAEA with certified reference material provided by the Agency.

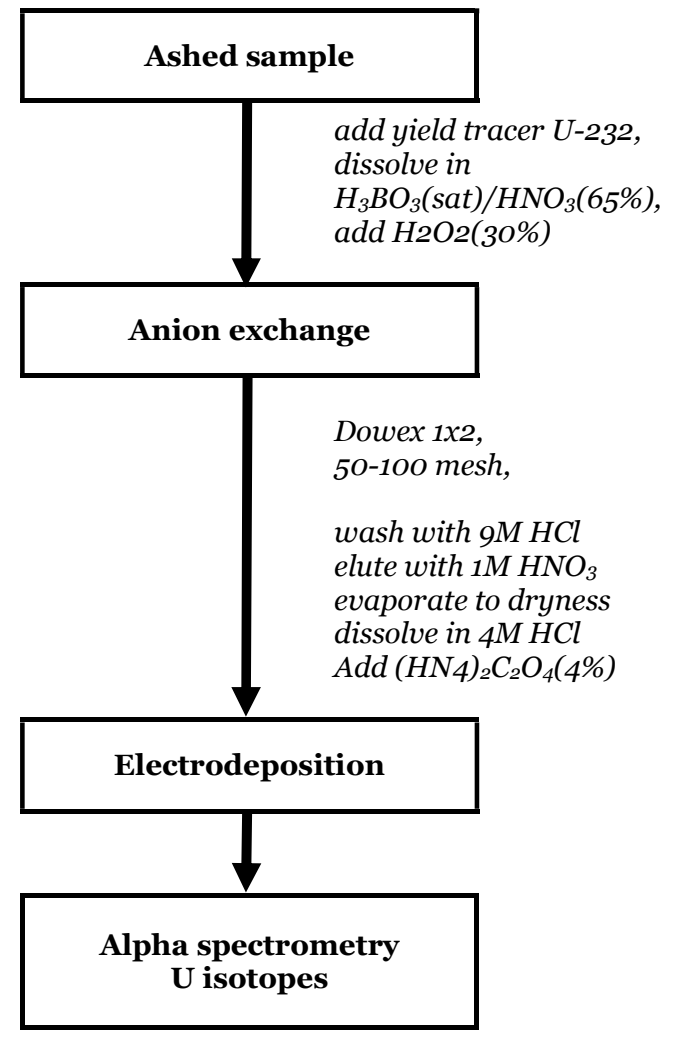

Figure 1. Scheme of the reduced analytical procedure used for $\mathrm{U}$ isotopes determination

To ensure the reliability and accuracy of the obtained results U-232 tracer (standard solution) was added at the beginning of each radioanalytical procedure. Where low percentage recovery and alpha spectra of not sufficient quality were obtained through the short procedure the sample anlysis was carried out according the full method.

95
Specific activities of U-234, U-235 and U-238 were calculated according to the following formulas:

$$
\begin{aligned}
& \mathrm{C}_{\mathrm{u}-234}=[\mathrm{I}(\mathrm{U}-234)-\mathrm{U}(234)] \mathrm{A}(232) / \mathrm{I}(232) \\
& \mathrm{C}_{\mathrm{u}-235}=[\mathrm{I}(\mathrm{U}-235)-\mathrm{U}(235)] \mathrm{A}(232) / \mathrm{I}(232) \\
& \mathrm{C}_{\mathrm{u}-238}=[\mathrm{I}(\mathrm{U}-238)-\mathrm{U}(238)] \mathrm{A}(232) / \mathrm{I}(232)
\end{aligned}
$$

where:

A (232) - the activity concentration of U-232 standard solution added to the sample;

I-234, I-235, I-238, I-232 - the integral area of U234, U-235, U-238 and U-232 respectively;

U (234), U (235), U (238) - background for U (234), U (235), U (238) respectively.

$\mathrm{U}(\mathrm{Bq} / \mathrm{kg})$ was calculated as sum of U-234, U-235 and $\mathrm{U}-238$ values.

$\mathrm{U}(\mathrm{mg} / \mathrm{kg})$ was calculated by the formula:

$\mathrm{A}=\lambda \mathrm{N}_{\mathrm{A}} / \mathrm{m}=\ln 2 \mathrm{~N}_{\mathrm{A}} / \mathrm{T}_{1 / 2} \mathrm{~m}$

where $\lambda$ is decay constant, $\mathrm{N}_{\mathrm{A}^{-}}$Avogadro constant, $\mathrm{m}$ mass of the radionuclide and $\mathrm{T}_{1 / 2}-$ half-life.

\section{RESULTS AND DISCUSSION}

Results of analyses of $U$ content in foodstuffs from the regions of Plovdiv and Haskovo are presented in Table 1 (dry weight) at up to $20 \%$ uncertainty for $\mathrm{k}=\mathbf{2}$.

Analyses were carried out to determine activity concentration of $U$ isotopes with the aim to evaluate possible radiological hazard. No deviation of U$238 / U_{324}$ ratio was observed and no increase of U-234 over radioactive equilibrium concentration and results obtained were considered not of risk for human health from radioactive point of view.

$\mathrm{U}$ content in foodstuff samples was calculated in $\mathrm{mg} / \mathrm{kg}$ to assess possible chemical toxicity. Most of the data published in literature is in $\mathrm{mg} / \mathrm{kg}$ and varies on a large scale. Results obtained in the present study were comparable with data reported in literature for foodstuffs from other regions of past uranium mining in the world $[17,18,19]$.

There are no reference values for $\mathrm{U}$ in foods. To evaluate to a certain extent the risk for human health results were analysed in the context of the reference values set for natural uranium in drinking water (0.03 $\mathrm{mg} / \mathrm{l})$ taking into consideration they are conservative and calculated on the basis of 21 daily intake. From this point of view $U$ content in foodstuffs was assessed as not hazardous to the population in both regions of study.

No significant difference was observed between the values from the region of Plovdiv and these of Haskovo. A relatively high concentration of natural uranium was determined in alfalfa from both regions, mainly used as animal feed, also reported by other countries such as the United States [20]. 
R. Lazarova et al., Uranium in foodstuff samples from two regions..., RAD Conf. Proc., vol. 3, 2018, 94-97

Table 1. Uranium content in foodstuff samples (dry weight) from the regions of Plovdiv and Haskovo

\begin{tabular}{|c|c|c|}
\hline \multirow[t]{2}{*}{ Sample } & U-234 & U-235 \\
\hline & $\mathrm{Bq} / \mathrm{kg}$ & $\mathrm{Bq} / \mathrm{kg}$ \\
\hline \multicolumn{3}{|l|}{$\begin{array}{l}\text { From the region of } \\
\text { Plovdiv }\end{array}$} \\
\hline Minced meat & 0.020 & 0.005 \\
\hline Carrots & 0.020 & 0.005 \\
\hline Potatoes & 0.042 & 0.005 \\
\hline Fresh milk & 0.010 & 0.005 \\
\hline Tomato concentrate & 0.020 & 0.005 \\
\hline Dried alfalfa & 0.520 & 0.020 \\
\hline \multicolumn{3}{|l|}{$\begin{array}{l}\text { From the region of } \\
\text { Haskovo }\end{array}$} \\
\hline Minced meat & 0.050 & 0.005 \\
\hline Carrots & 0.004 & 0.001 \\
\hline Potatoes sample 1 & 0.020 & 0.005 \\
\hline Potatoes sample 2 & 0.050 & 0.005 \\
\hline Fresh milk & 0.035 & 0.002 \\
\hline Dried alfalfa & 1.000 & 0.020 \\
\hline \multicolumn{3}{|l|}{ 4. CONCLUSIONS } \\
\hline \multicolumn{3}{|c|}{$\begin{array}{l}\text { As a result of the present study, the following } \\
\text { nclusions could be drawn: }\end{array}$} \\
\hline \multicolumn{3}{|c|}{$\begin{array}{l}\text { 1. The short procedure for uranium isotopes } \\
\text { analyzes could be used as a screening method } \\
\text { of informative nature for measuring natural } \\
\text { uranium in foodstuffs. }\end{array}$} \\
\hline \multicolumn{3}{|c|}{$\begin{array}{l}\text { 2. Results showed that uranium concentrations } \\
\text { measured in foodstuffs from the studied } \\
\text { regions of Plovdiv and Haskovo are } \\
\text { comparable with those cited in literature for } \\
\text { past uranium cites and were considered not } \\
\text { radiologically hazardous to the population. }\end{array}$} \\
\hline
\end{tabular}

\section{REFERENCES}

1. Sources and Effects of Ionizing Radiation, vol. 1, Annex A, UNSCEAR, New York (NY), 2000.

Retrieved from:

http://www.unscear.org/docs/publications/2000/UNS CEAR 2000 Annex-A.pdf;

Retrieved on: May 15. 2018

2. Sources and Effects of Ionizing Radiation, Annex A, New York (NY), 1993

Retrieved from:

http://www.unscear.org/docs/publications/1993/UNS CEAR 1993 Annex-A.pdf;

Retrieved on: Apr. 12, 2018

3. M. L. Montes, R. C Mercader, A. Taylor, J. Runco, J. Desimoni, "Assessment of natural radioactivity levels and their relationship with soil characteristics in undisturbed soils of northeast of Buenos Aires province, Argentina," J. Environ. Radioact., vol. 105, pp. 30 - 39, Feb. 2012.

DOI: 10.1016/j.jenvrad.2011.09.014 
R. Lazarova et al., Uranium in foodstuff samples from two regions..., RAD Conf. Proc., vol. 3, 2018, 94-97

Retrieved from: https://www.wabd.bg/docs/Zakoni/N AR9.pdf;

Retrieved on: Apr. 12, 2018

10. G. Welford, R. Baird, "Uranium levels in human diet and biological materials," Health Phys., vol. 13, no. 12, pp. $1321-1324$, Dec. 1967.

DOI: 10.1097/00004032-196712000-00005

PMid: 6069847

11. I. Fisenne, P. Perry, K. Decker, H. Keller, "The daily intake of $234,235,238 \mathrm{U}, 228,230,232 \mathrm{Th}$ and ${ }^{226,228} \mathrm{Ra}$ by New York City residents," Health Phys., vol. 53, no. 4, pp. $357-363$, Oct. 1987.

DOI: 10.1097/00004032-198710000-00002 PMid: 3654223

12. T. Nozaki, M. Itchikawa, T. Sasuga, M. Inarida, "Neutron activation analysis of uranium in human bone, drinking water and daily diet," J. Radioanal. Nucl. Chem., vol. 6, no. 1, pp. 33 - 40, Sep. 1970. DOI: $10.1007 / \mathrm{BF} 2513897$

13. E. Hamilton, "The concentration of uranium in man and his diet," Health Phys., vol. 22, no. 2, pp. 149 - 153, Feb. 1972.

DOI: 10.1097/00004032-197202000-00004 PMid: 5067039

14. M. Kumar, S. Prasher, S. Singh, "Uranium analysis in some food samples collected from Bathinda area of Punjab, India,” Indian J. Phys., vol. 83, no. 7, pp. $1045-1050,2009$. DOI: 10.1007/s12648-009-0066-3

М. Найденов, И. Йорданова, Д. Станева, Л. Мишева, Сборник методики за определяне на алфа, бета и гама емитиращи радиоактивни изотопи в обекти от околната среда, Нациоален центьр за аграрни науки, София, България, 2001, стр. 25 - 29. (M. Naydenov. I. Yordanova. D. Staneva. L. Misheva,
Procedures for determination of alpha- beta- and gamma-emitting radioactive isotopes in environmental samples, National Center for Agricultural Science, Sofia, Bulgaria, pp. 25 - 29, 2001.)

15. M. Pimpl, B. Yoo, I. Yordanova, "Optimization of a radioanalytical procedure for the determination of uranium isotopes in environmental samples," J. Radioanal. Nucl. Chem., vol. 161, no 2. pp. 437 - 441, Aug. 1992. DOI: $10.1007 / \mathrm{BF} 02040490$

16. M. Anke, O. Seeber, O. Müller, U. Schäfer, J. Zerull, "Uranium transfer in the food chain from soil to plants, animals and man," Chemie der Erde-Geochemistry, vol. 69, pp. 75 - 90, Feb. 2009. DOI: $10.1016 / j . c h e m e r .2007 .12 .001$

17. M. O. Neves, M. M. Abreu, V. R. Figueiredo, "Uranium in vegetable foodstuffs: should residents near the Cunha Baixa uranium mine site (Central Northern, Portugal) be concerned?” Environ. Geochem. Health, vol. 34, pp. 181 - 189, Apr. 2012. DOI: $10.1007 / \mathrm{s} 10653-011-9428-9$

18. F. P Carvalho, J. M. Oliveira, O. Neves, M. M. Abreu, E. M. Vicente, "Soil to plant (Solanum tuberosum L.) radionuclide transfer in the vicinity of an old uranium mine," Geochem. Explor. Environ. Anal., vol. 9. no. 3, pp. 275 - 278, Jul. 2009 DOI: $10.1144 / 1467-7873 / 09-213)$

19. E. Baratta, P. Mackill, "Determination of uranium in food and water," J. Radioanal. Nucl. Chem., vol. 248, no. 2, pp. 473 - 475, May 2001. DOI: 10.1023/A:1010617200963 